\title{
Foliar Absorption of Urea, Ammonium, and Nitrate by Perennial Ryegrass Turf
}

\author{
Daniel C. Bowman \\ Department of Plant Science, University of Nevada, Reno, NV 89557 \\ Jack L. Paul \\ Department of Environmental Horticulture, University of California, Davis, CA 95616 \\ Additional index words. Lolium perenne, nitrogen nutrition, nitrogen assimilation
}

\begin{abstract}
The absorption and assimilation of ${ }^{15} \mathrm{~N}$-labeled urea, ( $\left.\mathrm{NH}_{4}\right)_{2} \mathrm{~S} \mathrm{O}_{4}$, and KNO $\mathrm{K}_{3}$ applied to the foliage of perennial ryegrass (Lolium perenne L.) turf were examined under a controlled environment. Each source of $\mathbf{N}$ was dissolved in deionized water to a final concentration of $25 \mathrm{~g}$ N/liter and spray-applied at a rate of $5 \mathrm{~g} N / \mathrm{m}^{2}$. Absorption of the fertilizer- $\mathrm{N}$ over 48 hours, as measured by ${ }^{15} \mathrm{~N}$ analysis of tissue digests, amounted to $35 \%, 39 \%$, and $40 \%$ for the urea, $\left(\mathrm{NH}_{4}\right)_{2} \mathrm{SO}_{4}$, and $\mathrm{KNO}_{3}$, respectively. Absorption was also estimated by a washing procedure that measured the urea remaining on the foliage and by the increase in total $N$ in the ryegrass tissue. There were no significant differences between the three methods for absorption of $\left(\mathrm{NH}_{4}\right) 2 \mathrm{SO}_{4}$ and $\mathrm{KNO}_{3}$. The washing method, however, significantly overestimated absorption of urea. Partitioning of the absorbed $\mathrm{N}$ between tissues was similar at 48 hours for all three $N$ sources, averaging $32 \%$ in new leaves, $52 \%$ in old leaves and shoot tissue, and $16 \%$ in the roots. Most of the absorbed urea- and $\mathrm{NH}_{4}-\mathrm{N}$ was assimilated by 48 hours, whereas only half of the $\mathrm{NO}_{3}-\mathrm{N}$ was reduced during that period.
\end{abstract}

The potential for fertilizing plants using foliar sprays has been recognized for many years. Numerous studies conducted during the 1950s clearly demonstrated that urea is rapidly absorbed by the leaves of numerous species (Cain, 1956; Cook and Boynton, 1952; Freiberg and Payne, 1957; Impey and Jones, 1960). Today the practice is generally limited to horticultural crops, such as fruit trees and turfgrass. The commercial home lawn care industry, for example, often uses foliar applications of soluble $\mathrm{N}$ fertilizers (Wesely et al., 1986).

Urea is one of the most common $\mathrm{N}$ sources used for foliar applications because it is highly soluble, inexpensive, and has a relatively low potential for injuring foliage. Wittwer et al. (1963) have suggested that urea is absorbed more rapidly by leaves than either $\mathrm{NO}_{3}$ or $\mathrm{NH}_{4}^{+}$, presumably because nonpolar substances, such as urea, diffuse through the cuticle more readily. As a result, most investigations of the foliar absorption of $\mathrm{N}$ have evaluated urea as the only source of $\mathrm{N}$.

Considerably fewer studies have examined the foliar application of other $\mathrm{N}$ fertilizers. Weinbaum and Neumann (1977) reported that $\mathrm{NO}_{3}-\mathrm{N}$ is absorbed, assimilated, and transported by prune leaves. Tomato leaves were also found capable of absorbing both $\mathrm{NO}_{3}$ and $\mathrm{NH}_{4}^{+}$, but in insufficient amounts for optimum growth (Magalhaes and Wilcox, 1983). Although it is apparent from these studies that inorganic $\mathrm{N}$ salts are absorbed by leaves, quantitative data on the extent and pattern of foliar uptake of $\mathrm{NO}_{3}^{-}$and $\mathrm{NH}_{4}^{+}$are lacking. Additionally, we are unaware of studies comparing foliar uptake of urea, $\mathrm{NO}_{3}$, and $\mathrm{N} \mathrm{H}_{4}^{+}$.

This study was undertaken to compare the absorption of $\mathrm{N}$, supplied as either urea, $\left(\mathrm{NH}_{4}\right) 2 \mathrm{SO}_{4}$, or $\mathrm{KNO}_{3}$, by the foliage of perennial ryegrass turf. Three methods of estimating foliar absorption were compared. First, $\mathrm{N}$ uptake was measured directly as ${ }^{15} \mathrm{~N}$ enrichment of tissue $\mathrm{N}$ following application of ${ }^{15} \mathrm{~N}$ labeled urea, $\left(\mathrm{NH}_{4}\right)_{2} \mathrm{SO}_{4}$, or $\mathrm{KNO}_{3}$. Uptake was also estimated

Received for publication 17 Dec. 1990. This research was supported by Isotope Services, Inc. (Los Alamos, N.M.). The cost of publishing this paper was defrayed in part by the payment of page charges. Under postal regulations, this paper therefore must be hereby marked advertisement solely to indicate this fact. by a) the difference between applied $\mathrm{N}$ and $\mathrm{N}$ remaining on the foliage over time, as measured by a washing procedure, and b) a Kjeldahl procedure to determine the increase in $\mathrm{N}$ content of the tissue.

\section{Materials and Methods}

Perennial 'Manhattan II' ryegrass was grown from seed in 1.0-liter round plastic pots filled with $1000 \mathrm{~g}$ of medium fine sand. Four hundred milligrams of seed per pot $\left(\approx 325 \mathrm{~kg} \bullet \mathrm{ha}^{-1}\right)$ was sown in Feb. 1986. Following germination, the turf was grown for 6 months under natural light in a greenhouse operated at 20/13C (day/night). The pots were irrigated with half-strength Hoagland's nutrient solution (Hoagland and Arnon, 1950) every 2 to 3 days and mowed as needed at $3 \mathrm{~cm}$. The final mowing occurred 6 days before treatments were applied.

All pots were transferred to a walk-in controlled environment growth chamber $48 \mathrm{~h}$ before $\mathrm{N}$ treatment. The chamber was maintained at $23 / 14 \mathrm{C}$ (day/night), $\approx 8090$ relative humidity, with a 14-h photoperiod and a light intensity of $400 \mu \mathrm{mol} \cdot \mathrm{m}^{-2} \cdot \mathrm{s}^{-1}$ at plant height. The pots were thoroughly leached with deionized water $24 \mathrm{~h}$ before $\mathrm{N}$ application to remove inorganic $\mathrm{N}$ from the leaves and sand. The turf in each pot was then clipped to a uniform height of $6 \mathrm{~cm}$. This resulted in a canopy consisting of an upper $3-\mathrm{cm}$ layer of new leaves above the normal mowing height and a lower 3-cm layer of older leaves and shoot material between the soil and the normal mowing height.

One hour after the start of the photoperiod, all pots were removed from the growth chamber. The pots were positioned within a marked area measuring $60 \mathrm{~cm}$ square on centers $\approx 14$ $\mathrm{cm}$, with the foliage canopy edge to edge. The appropriate $\mathrm{N}$ solution was applied by uniformly spraying the entire $0.36-\mathrm{m}^{2}$ area using a hand-held spray bottle. Solutions of unlabeled $\mathrm{N}$ as urea, $\mathrm{NH}_{4}$, or $\mathrm{NO}_{3}^{-}$were spray-applied to 12 pots each at a rate of $78 \mathrm{mg} \mathrm{N}$ per pot $\left(5 \mathrm{~g} \mathrm{~N} / \mathrm{m}^{2}\right.$, based on the turf canopy diameter of $14.1 \mathrm{~cm}$ ) in the equivalent of $200 \mathrm{ml}$ deionized water plus $0.1 \%(\mathrm{v} / \mathrm{v})$ Triton X-100 surfactant $/ \mathrm{m}^{2}$. Four additional pots for each $\mathrm{N}$ source were designated for harvest at 48 h. These were sprayed separately with identical solutions, but containing ${ }^{15} \mathrm{~N}$-labeled urea, $\left(\mathrm{NH}_{4}\right)_{2} \mathrm{SO}_{4}$, or $\mathrm{KNO}_{3}$ with ${ }^{15} \mathrm{~N}$ en- 
richments of $9.90 \%, 13.9390$, and $12.91 \%$, respectively. All pots were then returned to the growth chamber and were subirrigated daily with $80 \mathrm{ml}$ minus-N Hoagland's solution.

Four replicate pots from each $\mathrm{N}$ treatment were harvested at $\mathrm{O}, 12,24$, and $48 \mathrm{~h}$, with the last set being the ${ }^{15} \mathrm{~N}$-treated pots. At each harvest, the turf was excised by layer into new leaves, old leaves plus shoot material, and roots. Nitrogen remaining on the leaves and shoots was washed off and analyzed as described by Bowman and Paul (1989). Roots were separated from the sand by gentle washing in a stream of water. In the case of the time $\mathrm{O}$ samples, $\mathrm{N}$ spray reaching the sand was extracted in 1 liter of water, during which time the roots were separated. Tissues were dried at $65 \mathrm{C}$ for $24 \mathrm{~h}$ and ground.

Urea- $\mathrm{N}, \mathrm{NH}_{4}-\mathrm{N}$, and $\mathrm{NO}_{3}-\mathrm{N}$ in the washing solutions were determined by the rapid diffusion method (Carlson, 1986); urea was first hydrolyzed to $\mathrm{NH}_{4}^{+}$with jackbean urease (Sigma, St. Louis). Urea-N, $\mathrm{NH}_{4}-\mathrm{N}$, and $\mathrm{NO}_{3}-\mathrm{N}$ in the tissue were determined in an aqueous extract using $50 \mathrm{mg}$ of tissue in $15 \mathrm{ml}$ deionized water. Reduced $\mathrm{N}$ in the tissue was measured using a micro-Kjeldahl procedure (Carlson, 1978). ${ }^{15} \mathrm{~N}$-enrichment of the tissue $\mathrm{N}$ was determined by mass spectrometry. The experiment was conducted using a completely randomized split-plot design with $\mathrm{N}$ source as the main plot and method of estimating absorption as the subplot, with four replicates per treatment. Initial positioning of the applied $\mathrm{N}$ and uptake data from the final harvest were analyzed by analysis of variance and means separated by least significant difference.

\section{Results}

The distribution of $\mathrm{N}$ between new leaves, old leaves, and soil following spray application was very similar for the three forms of $\mathrm{N}$ (Table 1). Most of the $\mathrm{N}$ was located on the new and old leaves, in about equal amounts. Very little $\mathrm{N}$ reached the soil. Total recovery of the fertilizer $\mathrm{N}$ at time $\mathrm{O}$, as determined by washing, averaged $77.3 \pm 3.6 \mathrm{mg} \mathrm{N}$ per pot across the three sources of N. By comparison, the calculated application, based on a 14 . 1-cm canopy diameter, was $78 \mathrm{mg} \mathrm{N}$ per pot.

Application of $\left(\mathrm{NH}_{4}\right)_{2} \mathrm{SO}_{4}$ and $\mathrm{KNO}_{3}$ caused moderate tissue damage characterized by an overall desiccation of some of the leaves by $12 \mathrm{~h}$. No damage was noted with the urea spray until $24 \mathrm{~h}$, when a collapse and bleaching of the cut leaf tips, $\approx 1$ $\mathrm{cm}$ long, was noted. Unlike the desiccation caused by the two salts, urea damage had worsened by $48 \mathrm{~h}$.

There was relatively good agreement between the three methods for estimating $\mathrm{N}$ uptake from $\left(\mathrm{NH}_{4}\right)_{2} \mathrm{SO}_{4}$ and $\mathrm{KNO}_{3}($ Table 2). However, assuming the ${ }^{15} \mathrm{~N}$ data accurately represent $\mathrm{N}$ absorption, the washing method significantly overestimated uptake of urea. There was no difference in total $\mathrm{N}$ absorbed among the

Table 1. The initial position and recovery of urea- $\mathrm{N}, \mathrm{NH}_{4}-\mathrm{N}$, and $\mathrm{NO}_{3}-\mathrm{N}$ on perennial ryegrass 10 min following application at $5 \mathrm{~g}$ $\mathrm{N} / \mathrm{m}^{\mathrm{z}}$.

\begin{tabular}{lcccc}
\hline \hline & \multicolumn{4}{c}{ Recovery of applied N $\left(\mathrm{g} \mathrm{N} / \mathrm{m}^{2}\right)$} \\
\cline { 2 - 5 } & \multicolumn{3}{c}{ Leaves } & \\
\cline { 2 - 5 } N Source & New & Old & Soil & Total \\
\hline \hline Urea & $2.15^{\mathrm{z}}$ & 2.85 & 0.09 & 5.09 \\
$\left(\mathrm{NH}_{4}\right)_{2} \mathrm{SO}_{4}$ & 2.39 & 2.24 & 0.06 & 4.69 \\
$\mathrm{KNO}_{3}$ & 2.44 & 2.49 & 0.16 & 5.09 \\
$\mathrm{LSD}_{0.05}$ & $\mathrm{NS}$ & 0.42 & 0.03 & $\mathrm{NS}$ \\
\hline \hline
\end{tabular}

${ }^{2}$ Values are means of four samples.

${ }^{\mathrm{Ns}}$ Nonsignificant $(\mathrm{P}>0.05)$.
Table 2. Absorption of urea-N, $\mathrm{NH}_{4}-\mathrm{N}$, and $\mathrm{NO}_{3}-\mathrm{N}$ by perennial ryegrass after $48 \mathrm{~h}$ as estimated by a) measuring $\mathrm{N}$ remaining on foliage with a washing procedure, b) measuring increase in total $\mathrm{N}$ in tissue by Kjeldahl analysis, and c) ${ }^{15} \mathrm{~N}$ analysis of tissue.

\begin{tabular}{llcc}
\hline \hline & \multicolumn{3}{c}{$\mathrm{N}$ absorption } \\
\cline { 2 - 4 } Method & Urea & $\left(\mathrm{NH}_{4}\right)_{2} \mathrm{SO}_{4}$ & $\mathrm{KNO}_{3}$ \\
\hline \hline Washing & $66.9^{z}$ & 47.7 & 45.5 \\
Kjeldahl & 38.4 & 40.7 & 46.5 \\
${ }^{15} \mathrm{~N}$ analysis & 34.9 & 38.9 & 40.4 \\
\hline
\end{tabular}

${ }^{2}$ Values are means of four samples; LSD between method of analysis values $=10.3(\mathrm{P}=0.05) ;$ LSD between $\mathrm{N}$ source values $=11.0$ $(\mathrm{P}=0.05)$.

Table 3. The distribution of absorbed urea-N, $\mathrm{NH}_{4}-\mathrm{N}$, and $\mathrm{NO}_{3}-\mathrm{N}$ in the new and old leaves and in roots of perennial ryegrass, determined by ${ }^{15} \mathrm{~N}$ content of the tissue $48 \mathrm{~h}$ after application.

\begin{tabular}{|c|c|c|c|}
\hline \multirow[b]{3}{*}{ N Source } & \multicolumn{3}{|c|}{ Absorbed ${ }^{15} \mathrm{~N}$ in tissue (\%) } \\
\hline & \multicolumn{2}{|c|}{ Leaves } & \multirow[b]{2}{*}{ Roots } \\
\hline & New & Old & \\
\hline Urea & $30.3^{z}$ & 53.1 & 16.6 \\
\hline$\left(\mathrm{NH}_{4}\right)_{2} \mathrm{SO}_{4}$ & 30.8 & 52.6 & 16.6 \\
\hline $\mathrm{KNO}_{3}$ & 34.8 & 51.4 & 13.8 \\
\hline $\mathrm{LSD}_{0.05}$ & NS & NS & 1.5 \\
\hline
\end{tabular}

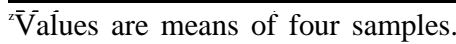

${ }^{\mathrm{Ns}}$ Nonsignificant $(\mathrm{P}>0.05)$.

three $\mathrm{N}$ sources as determined by either the tissue $\mathrm{N}$ (Kjeldahl) or the ${ }^{15} \mathrm{~N}$ method, with uptake averaging $\approx 40 \%$ of applied $\mathrm{N}$. The partitioning of absorbed ${ }^{15} \mathrm{~N}$ between new leaves, old leaves, and roots at $48 \mathrm{~h}$ was also very similar among the three sources of $\mathrm{N}$ (Table 3), with the old leaves containing half of the absorbed $\mathrm{N}$. Roughly $15 \%$ of the $\mathrm{N}$ was found in the roots even though only $2 \%$ of the applied $\mathrm{N}$ was located in the soil following application (Table 1).

Based on the data in Table 2, the disappearance of applied $\mathrm{N}$ from the foliage, as determined by the washing procedure, may be assumed to approximate the pattern of absorption of $\mathrm{NO}_{3}-\mathrm{N}$ and $\mathrm{NH}_{4}-\mathrm{N}$, but not urea. This argument is based on the fact that the washing method was similar in accuracy to the ${ }^{15} \mathrm{~N}$ method for estimating absorption of $\mathrm{NO}_{3}-\mathrm{N}$ and $\mathrm{NH}_{4}-\mathrm{N}$, and again assumes the ${ }^{15} \mathrm{~N}$ data accurately represent $\mathrm{N}$ absorption. Absorption of these two forms of N (Fig. 1) was most rapid during the first $12 \mathrm{~h}$, averaging $0.52 \mathrm{~g} \mathrm{~N} / \mathrm{m}^{2}$ (canopy area basis) for the new leaves and $0.94 \mathrm{~g} \mathrm{~N} / \mathrm{m}^{2}$ for the old leaves. Nitrate disappeared more slowly than either urea or $\mathrm{NH}_{4}^{+}$through 24 h. However, there was a slight increase in $\mathrm{NH}_{4}^{+}$on the tissue between 24 and $48 \mathrm{~h}$ while $\mathrm{NO}_{3}^{-}$continued to decrease, such that by $48 \mathrm{~h}$ there was no difference in the amounts of $\mathrm{NO}_{3}-\mathrm{N}$ and $\mathrm{NH}_{4}-\mathrm{N}$ remaining on the plant surface.

Reduced $\mathrm{N}$ in the tissue increased in the new and old leaves following foliar application of urea (Table 4) and $\left(\mathrm{NH}_{4}\right)_{2} \mathrm{SO}_{4}$ (Table 5) but not $\mathrm{KNO}_{3}$ (Table 6). Following application of urea, the concentration of free urea and $\mathrm{NH}_{4}^{+}$in the tissue increased substantially by $12 \mathrm{~h}$, with elevated levels being maintained through $48 \mathrm{~h}$. Similarly, with the application of $\left(\mathrm{NH}_{4}\right)_{2} \mathrm{SO}_{4}$, $\mathrm{NH}$ : in the tissue increased up to 13-fold in the old leaves, from 53 to $672 \mu \mathrm{g} \cdot \mathrm{g}^{-1}$, and up to nearly 100 -fold in the new leaves, from 29 to $2850 \mu \mathrm{g} \cdot \mathrm{g}^{-1}$. Nitrate levels rose from 1900 and 1700 to as high as 7100 and $3100 \mu \mathrm{g} \cdot \mathrm{g}^{-1}$ in the new and old leaves, respectively, in response to $\mathrm{KNO}_{3}$ application. There was thus substantial accumulation of nonmetabolized fertilizer 


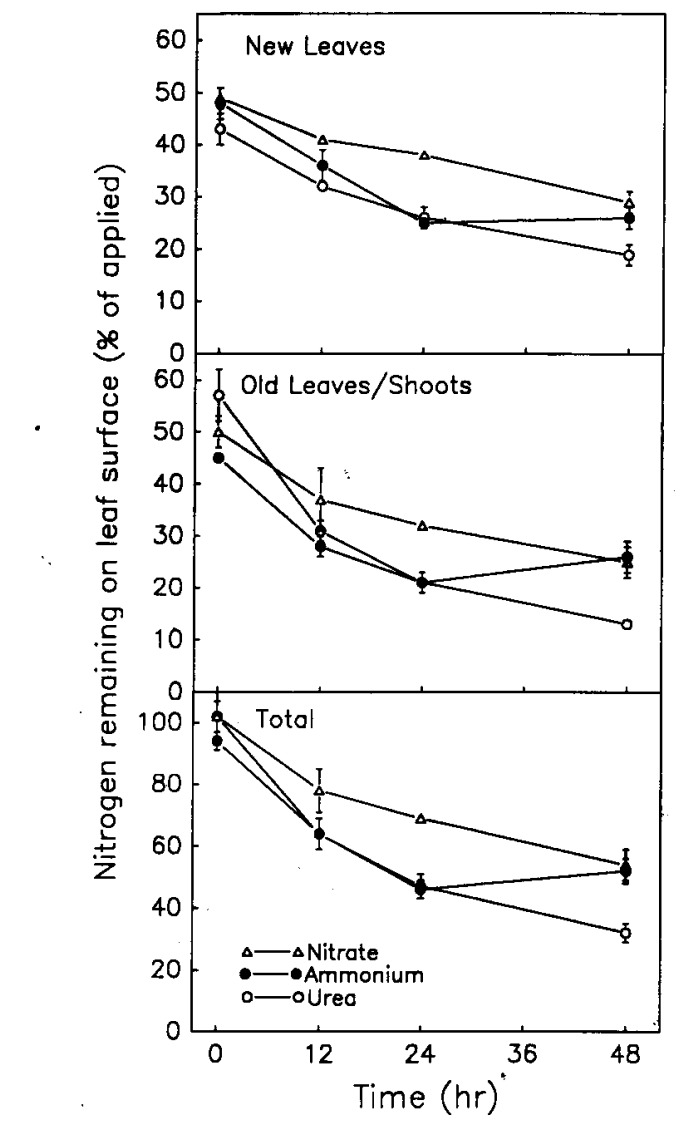

Fig. 1. Loss of urea-N, $\mathrm{NH}_{4}-\mathrm{N}$, and $\mathrm{NO}_{3}-\mathrm{N}$ from the new and old leaves of perennial ryegrass as determined by a washing procedure. Values are means of four samples \pm SD, where larger than the symbol.

$\mathrm{N}$ in the tissue that amounted to $13 \%, 16 \%$, and $49 \%$ of the absorbed urea, $\left(\mathrm{NH}_{4}\right)_{2} \mathrm{SO}_{4}$, and $\mathrm{KNO}_{3}$, respectively, based on uptake determined by ${ }^{15} \mathrm{~N}$ analysis. No changes were apparent in the levels of reduced $\mathrm{N}, \mathrm{NH}_{4}^{-} \mathrm{N}^{+}, \mathrm{NO}_{3}^{-}$, or urea in the roots.

\section{Discussion}

A previous study on the foliar uptake of urea by Kentucky bluegrass reported that both a washing and tissue $\mathrm{N}$ procedure gave estimates of absorption inconsistent with uptake determined by ${ }^{15} \mathrm{~N}$ analysis (Bowman and Paul, 1989). We suggested that the washing procedure overestimated uptake due to loss of applied urea through volatilization. Assuming that the difference between uptake estimated by washing and ${ }^{15} \mathrm{~N}$ analysis in the present study is due to volatilization, $\approx 30 \%$ of the applied urea-N was lost as $\mathrm{NH}_{3}$. That there was no statistical difference between the methods for estimating absorption of either $\left(\mathrm{NH}_{4}\right)_{2} \mathrm{SO}_{4}$ or $\mathrm{KNO}_{3}$ suggests that losses due to either volatilization or denitrification from these $\mathrm{N}$ sources was insignificant.

The absorption of urea by foliage is reportedly much greater than that of fertilizer salts (Wittwer et al., 1963). Therefore, we were surprised that the three $\mathrm{N}$ sources were absorbed to the same degree (Table 2) by perennial ryegrass. Likewise, Morris and Weaver (1983) reported that there was no significant difference in absorption between urea and $\left(\mathrm{NH}_{4}\right)_{2} \mathrm{SO}_{4}$ by the foliage of soybeans. This similarity in response to the $\mathrm{N}$ forms may indicate that absorption is by a common mechanism, independent of charge, such as simple diffusion through regions high in ectodesmata (Franke, 1967) or low in resistance. The considerable amount of the applied $\mathrm{N}$ remaining on the turf after $48 \mathrm{~h}$ implies that absorption may not be uniform across the leaf surface. For example, urea uptake is much more rapid by young leaves (Cain, 1956; Klein and Weinbaum, 1984) or by the underside of leaves for several species (Cain, 1956; Cook and Boynton, 1952; Freiberg and Payne, 1957; Impey and Jones, 1960).

Absorption of spray-applied ${ }^{15} \mathrm{~N}$ by perennial ryegrass in this study was comparable to uptake of urea previously reported for Kentucky bluegrass (43\%, Bowman and Paul, 1989), soybean (44\% to $69 \%$, Vasilas et al., 1980 ), corn (30\% to $34 \%$, Below et al., 1985), tea (44\%, Karasuyama et al., 1985) and six turfgrass species (31\% to $61 \%$, Wesely et al., 1985). The similarity in partitioning of the absorbed urea-, $\mathrm{NH}_{4}^{-}$, and $\mathrm{NO}_{3}-\mathrm{N}$ between tissues over the 48-h experimental period suggests that longer term $\mathrm{N}$ metabolism is controlled by factors other than the source

Table 4. Concentrations of reduced-N, $\mathrm{NH}_{4}-\mathrm{N}, \mathrm{NO}_{3}-\mathrm{N}$, and urea-N in perennial ryegrass tissue at various times following a foliar application of urea.

\begin{tabular}{|c|c|c|c|c|c|}
\hline \multirow{2}{*}{$\begin{array}{l}\text { Type of } \\
\text { tissue and } \\
\text { interval (h) }\end{array}$} & \multirow{2}{*}{$\begin{array}{l}\text { Reduced-N } \\
\text { (\% dry wt) }\end{array}$} & $\mathrm{NH}_{4}-\mathrm{N}$ & $\mathrm{NO}_{3}-\mathrm{N}$ & Urea-N & \multirow{2}{*}{$\begin{array}{c}\text { Absorbed N } \\
\text { unassimilated } \\
(\%) \\
\end{array}$} \\
\hline & & \multicolumn{3}{|c|}{$\mu \mathrm{g} \cdot \mathrm{g}^{-1}$ dry wt } & \\
\hline \multicolumn{6}{|l|}{ New leaves } \\
\hline 0 & $4.21 \pm 0.03^{y}$ & $50 \pm 3$ & $1898 \pm 964$ & $24 \pm$ & \\
\hline 12 & $4.53 \pm 0.09$ & $274 \pm 53$ & $926 \pm 610$ & $4387 \pm 1105$ & \\
\hline 24 & $4.93 \pm 0.04$ & $291 \pm 49$ & $903 \pm 311$ & $5062 \pm 996$ & \\
\hline 48 & $4.56 \pm 0.10$ & $226 \pm 29$ & $429 \pm 217$ & $2683 \pm 435$ & 8.6 \\
\hline \multicolumn{6}{|l|}{ Old leaves } \\
\hline 0 & $2.23 \pm 0.03$ & $67 \pm 1$ & $1706 \pm 465$ & $38 \pm$ & \\
\hline 12 & $2.37 \pm 0.07$ & $253 \pm 66$ & $999 \pm 314$ & $339 \pm$ & \\
\hline 24 & $2.43 \pm 0.03$ & $260 \pm 48$ & $934 \pm 269$ & $351 \pm$ & \\
\hline 48 & $2.34 \pm 0.10$ & $224 \pm 71$ & $855 \pm 355$ & $279 \pm$ & 4.3 \\
\hline \multicolumn{6}{|l|}{ Roots } \\
\hline 0 & $1.41 \pm 0.06$ & $48 \pm 14$ & $770 \pm 240$ & $28 \pm$ & \\
\hline 48 & $1.33 \pm 0.13$ & $26 \pm 4$ & $367 \pm 148$ & $6 \pm$ & \\
\hline
\end{tabular}

${ }^{2}$ The percent absorbed $\mathrm{N}$ unassimilated at $48 \mathrm{~h}$ is calculated as the ratio of the urea- $\mathrm{N}$ content in the tissue divided by the ${ }^{15} \mathrm{~N}$ content of the turf.

${ }^{y}$ Values are means of four samples \pm SD. 
Table 5. Concentrations of reduced-N, $\mathrm{NH}_{4}-\mathrm{N}$, and $\mathrm{NO}_{3}-\mathrm{N}$ in perennial ryegrass tissue at various times following application of $\left(\mathrm{NH}_{4}\right)_{2} \mathrm{~S} \mathrm{O}_{4}$.

\begin{tabular}{|c|c|c|c|c|}
\hline \multirow{2}{*}{$\begin{array}{l}\text { Type of } \\
\text { tissue and } \\
\text { interval (h) }\end{array}$} & \multirow{2}{*}{$\begin{array}{l}\text { Reduced-N } \\
(\% \text { dry wt) }\end{array}$} & $\mathrm{NH}_{4}-\mathrm{N}$ & $\mathrm{NO}_{3}-\mathrm{N}$ & \multirow{2}{*}{$\begin{array}{c}\text { Absorbed N } \\
\text { unassimilated } \\
(\%)\end{array}$} \\
\hline & & \multicolumn{2}{|c|}{$\mu g^{\cdot} g^{-1}$ dry wt } & \\
\hline \multicolumn{4}{|l|}{ New leaves } & \\
\hline 0 & $4.09 \pm 0.04^{y}$ & $29 \pm$ & $1898 \pm 964$ & \\
\hline 12 & $4.45 \pm 0.13$ & $1280 \pm 87$ & $762 \pm 366$ & \\
\hline 24 & $4.70 \pm 0.05$ & $2051 \pm 278$ & $653 \pm 251$ & \\
\hline 48 & $4.82 \pm 0.13$ & $2850 \pm 274$ & $378 \pm 106$ & 8.6 \\
\hline \multicolumn{5}{|c|}{ Old leaves } \\
\hline 0 & $2.20 \pm 0.06$ & $53 \pm$ & $1706 \pm 465$ & \\
\hline 12 & $2.39 \pm 0.05$ & $225 \pm 30$ & $1224 \pm 238$ & \\
\hline 24 & $2.42 \pm 0.04$ & $378 \pm 128$ & $977 \pm 360$ & \\
\hline 48 & $2.60 \pm 0.08$ & $672 \pm 26$ & $995 \pm 141$ & 7.3 \\
\hline \multicolumn{5}{|l|}{ Roots } \\
\hline 0 & $1.33 \pm 0.16$ & $39 \pm$ & $770 \pm 240$ & \\
\hline 48 & $1.51 \pm 0.03$ & $47 \pm$ & $573 \pm 96$ & \\
\hline
\end{tabular}

${ }^{2}$ The percent absorbed $\mathrm{N}$ unassimilated at 48 his calculated as the ratio of the $\mathrm{NH}_{4}-\mathrm{N}$ content in the tissue divided by the ${ }^{15} \mathrm{~N}$ content of the turf.

${ }^{y}$ Values are means of four samples \pm SD.

Table 6. The concentrations of reduced-N, $\mathrm{NH}_{4}-\mathrm{N}$, and $\mathrm{NO}_{3}-\mathrm{N}$ in perennial ryegrass tissue at various times following a foliar application of $\mathrm{KNO}_{3}$.

\begin{tabular}{|c|c|c|c|c|}
\hline \multirow{2}{*}{$\begin{array}{l}\text { Type of } \\
\text { tissue and } \\
\text { interval }(\mathrm{h}) \\
\end{array}$} & \multirow{2}{*}{$\begin{array}{l}\text { Reduced-N } \\
\text { (\% dry wt) }\end{array}$} & $\mathrm{NH}_{4}-\mathrm{N}$ & $\mathrm{NO}_{3}-\mathrm{N}$ & \multirow{2}{*}{$\begin{array}{c}\text { Absorbed N } \\
\text { unassimilated } \\
(\%)\end{array}$} \\
\hline & & \multicolumn{2}{|c|}{$\mu g \cdot g^{-1}$ dry wt } & \\
\hline \multicolumn{5}{|l|}{ New leaves } \\
\hline 0 & $4.23 \pm 0.12^{y}$ & $47 \pm 10$ & $1898 \pm 964$ & \\
\hline 12 & $3.82 \pm 0.05$ & $34 \pm 7$ & $4516 \pm 343$ & \\
\hline 24 & $4.07 \pm 0.11$ & $58 \pm 5$ & $7087 \pm 900$ & \\
\hline 48 & $4.11 \pm 0.04$ & $31 \pm 3$ & $5482 \pm 961$ & 17.3 \\
\hline \multicolumn{5}{|l|}{ Old Leaves } \\
\hline 0 & $2.18 \pm 0.11$ & $72 \pm$ & $1706 \pm 465$ & \\
\hline 12 & $2.10 \pm 0.03$ & $40 . \pm 5$ & $2332 \pm 501$ & \\
\hline 24 & $2.25 \pm 0.07$ & $46 \pm 11$ & $2774 \pm 982$ & \\
\hline 48 & $2.18 \pm 0.11$ & $50 \pm 11$ & $3126 \pm 659$ & 31.6 \\
\hline \multicolumn{5}{|l|}{ Roots } \\
\hline 0 & $1.31 \pm 0.04$ & $31 \pm 2$ & $770 \pm 240$ & \\
\hline 48 & $1.31 \pm 0.04$ & $26 \pm 2$ & $565 \pm 109$ & \\
\hline
\end{tabular}

${ }^{2}$ The percent absorbed $\mathrm{N}$ unassimilated at $48 \mathrm{~h}$ is calculated as the ratio of the $\mathrm{NO}_{3}-\mathrm{N}$ content in the tissue divided by the ${ }^{15} \mathrm{~N}$ content of the turf. The $\mathrm{NO}_{3}-\mathrm{N}$ content is corrected by the amount of $\mathrm{NO}_{3}-\mathrm{N}$ present in the tissues of the urea treatment.

'Values are means of four samples \pm SD.

of N, such as the relative sink strength of the tissues. The percentage of absorbed $\mathrm{N}$ translocated to the roots of perennial ryegrass, averaging $\approx 15 \%$, is identical to that for Kentucky bluegrass (Bowman and Paul, 1989) and similar to the $10 \%$ to $12 \%$ reported for olive (Klein and Weinbaum, 1984) following foliar application of urea. These values are in contrast to the $\leq 2 \%$ recovered in the roots of soybean (Morris and Weaver, 1983; Vasilas et al., 1980) and tea (Karasuyama et al., 1985).

The amount of fertilizer $\mathrm{N}$ associated with new leaves (both in the tissue and on the leaf surface) at $48 \mathrm{~h}$ was calculated as the sum of applied $\mathrm{N}$ remaining on the foliage, as determined by washing, plus the ${ }^{15} \mathrm{~N}$ content of the new leaves. Values ranged from 28.8 to $29.9 \mathrm{mg} \mathrm{N}$ per pot for the three $\mathrm{N}$ sources, or $\approx 38 \%$ of the $\mathrm{N}$ applied. Consequently, more than one-third of a typical $\mathrm{N}$ application could be lost with subsequent mowing and disposal of leaf clippings.

The metabolism of absorbed urea-N (Table 4) followed a pattern similar to that reported for Kentucky bluegrass (Bowman and Paul, 1989). Urea concentration in new and old leaves reached a maximum at 12 to $24 \mathrm{~h}$, decreasing slowly thereafter. The high level of $\mathrm{NH}_{4}^{+}$production measured in the 12-h samples indicates a very rapid initial hydrolysis of absorbed urea by leaf tissue. Application of $\left(\mathrm{NH}_{4}\right)_{2} \mathrm{SO}_{4}$ steadily increased tissue $\mathrm{NH}_{4}^{+}$levels in new and old leaves over the entire $48 \mathrm{~h}$ (Table 5). The $\mathrm{NH}_{4}^{+}$concentrations measured in the leaves between 12 and $48 \mathrm{~h}$ may have been high enough to inhibit photosynthesis (Puritch and Barker, 1967), which, in turn, would limit the synthesis of carbon substrate required to assimilate $\mathrm{NH}_{4}^{+}$and thus perpetuate the high $\mathrm{NH}_{4}^{+}$concentrations. Possibly, leaf desiccation due to the spray disrupted normal cellular function, allowing $\mathrm{NH}_{4}^{+}$to build up.

Following application of $\mathrm{KNO}_{3}$, tissue $\mathrm{NO}_{3}^{-}$increased 4-fold and 2-fold in the new and old leaves, respectively. Interestingly, reduced $\mathrm{N}$ in the tissues remained essentially unchanged with $\mathrm{KNO}_{3}$ application, unlike the increases in reduced $\mathrm{N}$ noted following application of either urea or $\left(\mathrm{NH}_{4}\right)_{2} \mathrm{SO}_{4}$. The $\mathrm{NO}_{3}^{-} \mathrm{ab}$ sorbed by the ryegrass foliage likely is principally stored in the vacuole. This vacuolar $\mathrm{NO}_{3}^{-}$would be released slowly, as demanded for growth. Consequently, the concentration of reduced $\mathrm{N}$ would remain fairly constant. Metabolism of endogenous $\mathrm{NO}_{3}^{-}$; was fairly similar in both the urea and $\mathrm{NH}_{4}^{+}$treatments.

We conclude from this study that perennial ryegrass absorbs foliar-applied urea, $\mathrm{KNO}_{3}$, and $\left(\mathrm{NH}_{4}\right)_{2} \mathrm{SO}_{4}$ equally well. Uptake of each $\mathrm{N}$ form is most rapid during the first $12 \mathrm{~h}$, decreases thereafter, with total absorption after $48 \mathrm{~h}$ being $\approx 40 \%$ of that applied. However, $\left(\mathrm{NH}_{4}\right)_{2} \mathrm{SO}_{4}$ and $\mathrm{KNO}_{3}$ caused unacceptable foliar damage and thus would be unsuitable for foliar fertilization at the concentration used in this study. Because more than one-third of the fertilizer $\mathrm{N}$ is retained on or in new leaf tissue, clippings should be returned to the turf. Where clippings are removed, increased fertilizer efficiency should result from irrigating the turf after $\mathrm{N}$ application, but before mowing, to wash the $\mathrm{N}$ off the leaves and into the soil.

\section{Literature Cited}

Below, F. E., S.J. Crafts-Brandner, J.E. Harper, and R.H. Hageman. 1985. Uptake, distribution, and remobilization of ${ }^{15} \mathrm{~N}$-labelled urea applied to maize canopies. Agron. J. 77:412415.

Bowman, D.C. and J.L. Paul. 1989. The foliar absorption of urea-N by Kentucky bluegrass turf. J. Plant Nutr. 12:659-673.

Cain, J.C. 1956. Absorption and metabolism of urea by leaves of coffee, cacao and banana. Proc. Amer. Soc. Hort. Sci. 67:279-286.

Carlson, R.M. 1978. Automated separation and conductimetric determination of ammonia and dissolved carbon dioxide. Anal. Chem. 50:1528-1531.

Carlson, R.M. 1986. Continuous flow reduction of nitrate to ammonia with granular zinc. Anal. Chem. 58:1590-1591.

Cook, J.A. and D. Boynton. 1952. Some factors affecting the absorption of urea by McIntosh apple leaves. Proc. Amer. Soc. Hort. Sci. 59:82-90.

Franke, W. 1967. Mechanisms of foliar penetration of solutions. Annu. Rev. Plant Physiol. 18:281-300.

Freiberg, S.R. and P. Payne. 1957. Foliar absorption of urea and urease activity in banana plants. Proc. Amer. Soc. Hort. Sci. 69:22G234.

Hoagland, D.R. and D.I. Arnon. 1950. The water culture method for growing plants without soil. Calif. Agr. Expt. Sta. Circ. 347.

Impey, R.L. and W.W. Jones. 1960. Rate of absorption of urea by 
intact leaves of Washington navel orange. Proc. Amer. Soc. Hort. Sci. 76:181-185.

Karasuyama, M., T. Yoneyama, and H. Kobayashi. 1985. ${ }^{15} \mathrm{~N}$ study on the fate of foliarly applied urea nitrogen in tea plant (Camellia sinensis L.). Soil Sci. Plant Nutr. 31:123-131.

Klein, I. and S.A. Weinbaum. 1984. Foliar application of urea to olive: Translocation of urea nitrogen as influenced by sink demand and nitrogen deficiency. J. Amer. Soc. Hort. Sci. 109:356-360..

Magalhaes, J.R. and G.E. Wilcox. 1983. Tomato growth, nitrogen fraction and mineral composition in response to nitrate and ammoniumfoliar sprays. J. Plant Nutr. 6:911-939.

Morris, D.R. and R.W. Weaver. 1983. Absorption and translocation of foliarly applied ${ }^{\text {ls }} \mathrm{N}$ by soy beans. Agron. J. 75:572-574

Puritch, G.S. and A.V. Barker. 1967. Structure and function of tomato leaf chloroplasts during ammonium toxicity. Plant Physiol. 42:12291238.

Vasilas, B. L., J.O. Legg, and D.C. Wolf. 1980. Foliar fertilization of soybeans: absorption and translocation of ${ }^{15} \mathrm{~N}$-labelled urea. Agron. J. 72:271-275.

Weinbaum, S.A. and P. M. Neumann. 1977. Uptake and metabolism of ${ }^{15} \mathrm{~N}$-labeled potassium nitrate by french prune (Prunus domestica L.) leaves and the effects of two surfactants. J. Amer. Soc. Hort. Sci. 102:601-604.

Wesely, R.W., R. C. Shearman, and E. J. Kinbacher. 1985. Foliar Nuptake by eight turfgrasses grown in controlled environment. J. Amer. Soc. Hort. Sci. 110:612-614.

Wesely, R. W., R.C. Shearman, and E.J. Kinbacher. 1986. Foliar uptake of liquid applied fertilizers, p. 41-50. In: B.G. Joyner (cd.). Advances in turfgrass fertility. Chemlawn Serv. Corp., Columbus, Ohio.

Wittwer, S. H., M.J. Bukovac, and H.B. Tukey. 1963. Advances in foliar feeding of plant nutrients, p. 429-455. In: M.H. McVickar, G.L. Bridger, and L.B. Nelson (eds.). Fertilizer technology and usage. Amer. Soc. Agron., Madison, Wis. 